\title{
Recent advances in non-intubated robotic-assisted thoracic surgery (NiRATS) for tracheal/airway resection and reconstruction
}

\author{
Volkan Kösek, Eyad Al Masri, Bassam Redwan \\ Department of Thoracic Surgery, Klinik am Park, Klinikum Westfalen, Lünen, Germany \\ Correspondence to: Bassam Redwan, MD. Department of Thoracic Surgery, Klinikum Westfalen, 44536 Lünen, Germany. Email: bassam.redwan@gmail.com. \\ Comment on: Li S, Ai Q, Liang H, et al. Non-intubated Robotic-Assisted Thoracic Surgery for Tracheal/Airway Resection and Reconstruction: \\ Technique Description and Preliminary Results. Ann Surg 2021. [Epub ahead of print]. doi: 10.1097/SLA.0000000000004887.
}

Submitted Sep 18, 2021. Accepted for publication Sep 29, 2021.

doi: $10.21037 / \mathrm{atm}-21-4986$

View this article at: https://dx.doi.org/10.21037/atm-21-4986

Li et al. report their initial experience with non-intubated robotic-assisted thoracic surgery (RATS) for tracheal/airway resection and reconstruction (1).

A total of 5 patients underwent RATS tracheal/airway surgery under the non-intubated setting. The authors conclude that the described technique represents a safe and feasible approach for tracheal and airway surgery in wellselected patients.

In a previous work of the same group, non-intubated video-assisted thoracic surgery (NiVATS) for resection of a tracheal mass and reconstruction of the trachea was described with satisfying results (2).

Early recovery after surgery (ERAS) is a very important issue in thoracic surgery. Implementation of minimally invasive surgical techniques supports this concept und accelerates the patient recovery. Over the last decade, a substantial evolution of the minimally invasive thoracic surgical techniques was marked. The utilization of the uniportal video-assisted thoracic surgery (uVATS) represents one of the most important milestones in thoracic surgery. Numerous studies have reported the safety and efficacy of this approach in a wide spectrum of thoracic surgical procedures (3-5).

Gonzalez-Rivas and colleagues reported their experience in bronchovascular, tracheal and carinal sleeve resections using the uniportal approach (4). The authors concluded that complex procedures such as tracheal resections may be performed safely in the hands of an experienced team. The minimally invasive approach minimizes the disadvantages of the open-surgical approach and facilitates postoperative recovery.

Robotic-assisted thoracic surgery (RATS) represents a further milestone of minimally invasive thoracic surgery. Safety and efficacy of RATS in anatomical lung resections and mediastinal tumor resections has been shown in several studies (6-8) and a reduction of postoperative pain was reported (9). However, regarding cost effectiveness, RATS does not seem to have an advantage over VATS (10).

A further important factor supporting ERAS is the implementation of NiVATS. Numerous thoracic surgical procedures are performed in the non-intubated setting with very promising results and growing acceptance among physicians and patients (11-14). In well-selected patients, this approach is associated with shorter hospital stay and more rapid recovery from surgery when compared with the intubated setting (15).

In the current case series by Li et al. the both RATS and the non-intubated setting were combined for tracheal/ airway resections and reconstructions (1). The authors reported operative times of $5 \mathrm{~h} 5 \mathrm{~min}$ to $9 \mathrm{~h} 55 \mathrm{~min}$ and postoperative hospital stays of 4 to 14 days. These reported times are longer than equivalent procedures when performed by VATS under the non-intubated setting $(4,16)$ and therefore lack advantage in terms of ERAS after tracheal surgery. This might be due to the initial difficulties encountered while implementing a new technique. Nevertheless, the combination of RATS and the nonintubated approach is a novel and innovative concept, which surely should be performed and further validated in a larger, patient cohort, to identify the patient subgroup, which 
would benefit the most of this novel concept.

\section{Acknowledgments}

Funding: None.

\section{Footnote}

Provenance and Peer Review: This article was commissioned by the editorial office, Annals of Translational Medicine. The article did not undergo external peer review.

Conflicts of Interest: All authors have completed the ICMJE uniform disclosure form (available at https://dx.doi. org/10.21037/atm-21-4986). BR serves as an unpaid editorial board member of Annals of Translational Medicine. The other authors have no conflicts of interest to declare.

Ethical Statement: The authors are accountable for all aspects of the work in ensuring that questions related to the accuracy or integrity of any part of the work are appropriately investigated and resolved.

Open Access Statement: This is an Open Access article distributed in accordance with the Creative Commons Attribution-NonCommercial-NoDerivs 4.0 International License (CC BY-NC-ND 4.0), which permits the noncommercial replication and distribution of the article with the strict proviso that no changes or edits are made and the original work is properly cited (including links to both the formal publication through the relevant DOI and the license). See: https://creativecommons.org/licenses/by-nc-nd/4.0/.

\section{References}

1. Li S, Ai Q, Liang H, et al. Non-intubated Robotic-Assisted Thoracic Surgery for Tracheal/Airway Resection and Reconstruction: Technique Description and Preliminary Results. Ann Surg 2021. [Epub ahead of print]. doi: 10.1097/SLA.0000000000004887.

2. Li S, Liu J, He J, et al. Video-assisted transthoracic surgery resection of a tracheal mass and reconstruction of trachea under non-intubated anesthesia with spontaneous breathing. J Thorac Dis 2016;8:575-85.

3. Gonzalez-Rivas D, Yang Y, Ng C. Advances in Uniportal Video-Assisted Thoracoscopic Surgery: Pushing the Envelope. Thorac Surg Clin 2016;26:187-201.

4. Gonzalez-Rivas D, Yang Y, Stupnik T, et al. Uniportal video-assisted thoracoscopic bronchovascular, tracheal and carinal sleeve resections $†$. Eur J Cardiothorac Surg 2016;49 Suppl 1:16-16.

5. Reinersman JM, Passera E, Rocco G. Overview of uniportal video-assisted thoracic surgery (VATS): past and present. Ann Cardiothorac Surg 2016;5:112-7.

6. Fok M, Bashir M, Harky A, et al. Video-Assisted Thoracoscopic Versus Robotic-Assisted Thoracoscopic Thymectomy: Systematic Review and Meta-analysis. Innovations (Phila) 2017;12:259-64.

7. Hu D, Wang Z, Tantai J, et al. Robotic-assisted thoracoscopic resection and reconstruction of the carina. Interact Cardiovasc Thorac Surg 2020;31:912-4.

8. Veronesi G, Novellis P, Voulaz E, et al. Robot-assisted surgery for lung cancer: State of the art and perspectives. Lung Cancer 2016;101:28-34.

9. van der Ploeg APT, Ayez N, Akkersdijk GP, et al. Postoperative pain after lobectomy: robot-assisted, video-assisted and open thoracic surgery. J Robot Surg 2020;14:131-6.

10. Chen D, Kang P, Tao S, et al. Cost-effectiveness evaluation of robotic-assisted thoracoscopic surgery versus open thoracotomy and video-assisted thoracoscopic surgery for operable non-small cell lung cancer. Lung Cancer 2021;153:99-107.

11. Gonzalez-Rivas D, Bonome C, Fieira E, et al. Non-intubated video-assisted thoracoscopic lung resections: the future of thoracic surgery? Eur J Cardiothorac Surg 2016;49:721-31.

12. Kiss G, Castillo M. Non-intubated anesthesia in thoracic surgery-technical issues. Ann Transl Med 2015;3:109.

13. Xue W, Duan G, Zhang X, et al. Comparison of nonintubated and intubated video-assisted thoracoscopic surgeries of major pulmonary resections for lung cancer-a meta-analysis. World J Surg Oncol 2021;19:87.

14. Pompeo E. State of the art and perspectives in nonintubated thoracic surgery. Ann Transl Med 2014;2:106.

15. Wang ML, Hung MH, Hsu HH, et al. Non-intubated thoracoscopic surgery for lung cancer in patients with impaired pulmonary function. Ann Transl Med 2019;7:40.

16. Peng G, Cui F, Ang KL, et al. Non-intubated combined with video-assisted thoracoscopic in carinal reconstruction. J Thorac Dis 2016;8:586-93.

Cite this article as: Kösek V, Al Masri E, Redwan B. Recent advances in non-intubated robotic-assisted thoracic surgery (NiRATS) for tracheal/airway resection and reconstruction. Ann Transl Med 2021;9(19):1510. doi: 10.21037/atm-21-4986 